\title{
Effect of Non-genetic Factors on Milk Production Traits of Pure Jersey Dairy Cattle in Central Highland Ethiopia
}

\author{
Nibo Beneberu ${ }^{1,2^{*}} \quad$ Wossenie Shibabaw $^{2} \quad$ Kefale Getahun $^{1} \quad$ Kefyalew Alemayehu ${ }^{2}$ \\ 1.Ethiopian Institute of Agricultural Research, Holetta Agricultural Research Center. PO Box 2003 Addis Ababa \\ or 31 Holetta, Ethiopia \\ 2.Bahir Dar University, Department of Animal Production and Technology, P.O.Box 2145, Bahir Dar, Ethiopia
}

\begin{abstract}
The study was conducted to investigate the effects of non-genetic factors on Milk production traits of pure Jersey dairy cattle semi-intensively managed at on station. A total of 2912 records from pure Jersey dairy cattle were collected from 1986 to 2019 and analysed by (SAS, version 9.0). The overall least squares mean (LSM \pm SE) for lactation milk yield (LMY), daily milk yield (DMY) and lactation length (LL) were 2166.10 26.71 Litres, $6.37 \pm 0.05$ Litres and $344.89 \pm 3.81$ days, respectively. Lactation milk yield (LMY), daily milk yield (DMY) and lactation length (LL) were influenced by non-genetic factors such as animal group, year and parity. But, milk production traits were not affected by calving season. Knowledge on the effect of these non-genetic factors on milk production traits would help in making management decisions for improvement of the herds.
\end{abstract}

Keywords: Milk, non-genetic factors, pure Jersey cows

DOI: $10.7176 / \mathrm{FSQM} / 103-02$

Publication date: December $31^{\text {st }} 2020$

\section{INTRODUCTION}

Ethiopia is one of the developing countries in Africa known with a huge livestock population. The estimated total cattle population for the country is about 61.59 million constituting of male $(44.77 \%)$ and female $(55.23 \%)$. Out of the total cattle population in the country, the proportions of indigenous breeds are $97.66 \%$ and the remaining hybrid and exotic breeds are about $2.00 \%$ and $0.34 \%$, respectively (CSA 2019/2020). The demands for dairy products are estimated to increase substantially as the human population increase in Ethiopia. In response to the increasing demand for dairy products, the Ethiopian government has been efforted to improve productivity in the livestock sector, through intensive husbandry with cross and exotic breeds (Million and Tadelle 2003; Firdessa 2012). However, the dairy sector in Ethiopia is still not developed compared to east African countries like Kenya, Tanzania and Uganda (Hunduma 2013).

Holstein-Friesian and Jersey breeds are the most common highly productive exotic dairy cattle breeds introduced in Ethiopia, and are important sources of milk and income, especially in urban areas. Despite this fact, the effect of non-genetic factors on milk production traits of these breeds are not well documented after the animals are introduced and distributed to specific locations (Hunduma 2013). Even though there is concern about adaptation problems of pure exotic dairy cattle to the tropical environment (feed, disease challenge and climate) pure Friesian and Jersey dairy breeds have been utilized by large scale private and state dairy farms in Ethiopia.

Milk production traits are the most economically important traits, contributing to the profitability of dairy production (Fikre et al. 2007). The common measures of milk production traits of dairy cattle are lactation milk yield (LMY), daily milk yield (DMY) and lactation length (LL). Non-genetic factors such as birth or calving year, parity of cow and birth or calving season of cattle influence the milk productive performance of dairy cattle, which should be considered in the selection for increased production and reproductive efficiency of dairy cattle (Olawumi and Salako 2010). Knowledge of these non-genetic factors and their influence on cattle milk productive performance is important in the formulation of management and selection decisions. However, information is lacking in this regard, and no study has yet been conducted to identify factors affecting milk production of pure Jersey dairy cattle. Hence, this study was conducted to determine influences of non-genetic factors on milk production traits of pure Jersey dairy cattle in central highland Ethiopia.

\section{MATERIALS AND METHODS}

Description of the study area and farm

The study was conducted at Adea-Berga dairy research center which is found in West Shewa Zone of Oromia regional state of Ethiopia. The site is located $70 \mathrm{~km}$ away to the West of Addis Ababa and $35 \mathrm{~km}$ to the North West of Holeta (at $9^{\circ} 16^{\prime} \mathrm{N}$ latitude and $38^{\circ} 23^{\prime} \mathrm{E}$ longitudes, altitude of $2500 \mathrm{~m}$ above sea level). It is characterized by cool sub-tropical climate with the mean annual temperature and rainfall of $18^{\circ} \mathrm{C}$ and $1225 \mathrm{~mm}$, respectively.

The farm was established in 1986 for commercial milk production under government state farm using 400 pure Jersey pregnant heifers and 2 sires (foundation stock) introduced from Denmark. The total area of the farm has 400 ha of land. Animal barn, office and residence were constructed on about 10 ha of land and the rest of 
land is being utilized for grazing and hay production. The whole pasture land is protected during main rainy season for hay production and also all animals are confined to the barn during this period. The farm had been engaged in the production and rearing of pure Jersey breed from the foundation stock for milk supply for dairy development enterprises and also serve as a bull dam station for the national artificial insemination center (NAIC). Then the farm was transferred to Holeta Agricultural Research Center for genetic improvement research program since 2007. The objectives of the farm were to increase milk production through pure breeding and production of pure breed Jersey bulls for AI and Natural mating (NM). The production system of the farm is semi-intensive production system.

\section{Study animals and their management}

Pure Jersey dairy cows were the study subjects. The animals were managed semi intensively. Herds are managed separately depending on sex, age, pregnancy and lactation (dry or milking). Female calves were allowed to suckle their dam immediately after birth for about five days to receive colostrum and then separated from their dams and offered fresh milk twice a day for about 6 months. However, male calves were weaned within 98 days. Weighting and ear tagging were also engaged within 24 hours after birth. Cows and heifers were allowed to graze natural pasture for about 4 hours a day and supplemented with hay, silage and concentrate feeds up on return to the barn during the dry and small rainy seasons. The animals had free access to clean tap water all the time. All animals were restricted from grazing and managed indoor during main rainy season. Calves less than 6 months, bulls and late pregnant cows and heifers were usually isolated and managed indoor. All animals were supplemented with hay and concentrate feeds constituting $60 \%$ wheat bran (sometimes with wheat middling), $38 \%$ noug seed cake (Guizotia abyssinica) and $2 \%$ salt. The amount consumed is not exactly known, since it depends up on the amount of feed available on the stock.

Milking machine was used for about one year in between 1988 and 1989. However, due to shortage of spare part and skilled man power for maintenance of the machine, the farm was forced to implement hand milking. Milking was done twice a day at equal interval (in the morning and afternoon) and the milk produced by each cow was measured and recorded on prepared format immediately after milking.

\section{Data source and data collection}

The data for this study was obtained from long-term records of pure Jersey breed that has been kept for dairy production in Adea-Berga dairy farm. There are four main recording formats; the first is a herd book containing daily breeding activity, the second is milk record format which contains daily milk yield, the third is health record and the fourth is individual card record in which individual complete data is prepared or transferred from herd book. Individual cards contain birth date, individual tag number, sex of calf, calf birth weight, dam and sire, service date, service sire, calving date, milk yield records, disposal date, cause of disposal and other reproductive and production data. There was computerized data base in the farm. Recorded data for the last 33 years (19862019) on milk production data were used for this study.

The data used in this study were collected from 1986 to 2019 from individual animal card history and from the center database for the subsequent trait analysis. Identification number of each cow date of calving, parity of cow, animal group, lactation milk yield (LMY), daily milk yield (DMY) and lactation length (LL) data were collected from the farm data base.

\section{Data management and description of fixed effects}

Milk production performance data collected from 1986-2019 at Adea-Berga dairy research center were used for this study. Microsoft Excel was used to arrange and filter milk production data. Screening of data was made to avoid errors during data entrance. Cows that had abnormal calving (i.e., abortion and stillbirths) were not included in the model analysis. During data editing lactation records having less than 100 days were removed from data set for analysis of lactation milk yield and lactation length. Lactation records of sixth and above parities were pooled due to few numbers of observations.

The major genetic and non-genetic effects were classified into different sub-classes in order to quantify their effect on the milk performance traits. The fixed effects were animal group, year, season and parity.

Animal group: Includes imported and farm bred (farm bred animals were the progeny of imported animal which have been raised in the farm).

Calving years: Years which used for this study were spread over span of 33 years and thus there could be variation in the expression of different economic traits over the years due to the effect of changing climatic, feeding and management factors in the herd. However, this effect might be insignificant to quantify for each year separately. This has been initially done and it was learnt that the economic traits didn't vary over the years in a consistent and meaningful manner as well as variation of number of observations. Consequently, it was decided to use period (year group) to account for its effect. Thus, the entire duration was classified in to 10-11 periods based calving years; each year period represents three years. 
Calving seasons: Seasons are considered as one of the environmental factors that affect the expression of economic traits. Thus, based on the meteorological information that considered temperature, rainfall and relative humidity three calving seasons were identified. Thus, the three seasons were dry season (October, November, December, January and February), short rain season (March, April and May) and main rain season (June, July, August and September).

Parity: Each cow included in the study contributed variable number of lactation records depending on the number of calvings. Thus, parity was fitted as fixed effect to account for its effect. Parity was grouped in to six classes $(1,2,3,4,5$ and $\geq 6)$. All parities above six were pooled with the $6^{\text {th }}$ parity because the available numbers of cow with parity greater than six were too small to constitute separate groups.

\section{Statistical analysis}

Preliminary data analysis like screening of outliers and normality test were employed before conducting the main data analysis. Effects of non-genetic factors (animal group, year, season and parity) and least squares mean for milk production traits (LMY, DMY and LL) were analysed by the GLM procedures of SAS (2004) version 9.0 software. Differences between least squares means of a trait for different genetic and non-genetic factors were tested using the Tukey-Kramer test based on the ANOVA result. Fixed effects which are significant $(\mathrm{P}<0.05)$ were fitted into the model. The statistical model for the three milk production traits was as follow:

Model: Statistical model for analysis of milk production traits (LMY, DMY and LL):

$\mathrm{Y}_{\mathrm{ijkl}}=\mu+\mathrm{Y}_{\mathrm{i}}+\mathrm{S}_{\mathrm{j}}+\mathrm{G}_{\mathrm{k}}+\mathrm{P}_{1}+\mathrm{e}_{\mathrm{ijkl}}$

Where:

$\mathrm{Y}_{\mathrm{ijkl}}=\mathrm{LMY}$, DMY and LL of ${ }_{\mathrm{ijkl}}$ cow with $\mathrm{i}^{\text {th }}$ year, $\mathrm{j}^{\text {th }}$ season, $\mathrm{k}^{\text {th }}$ genetic group and $\mathrm{l}^{\text {th }}$ parity

$\mu=$ overall mean;

$Y_{i}=$ the fixed effect of $i^{\text {th }}$ period of calving ( $i=1986$ to 2019)

$\mathrm{S}_{\mathrm{j}}=$ the fixed effect of $\mathrm{j}^{\mathrm{th}}$ season of calving (dry, short rain and main rain season)

$\mathrm{G}_{\mathrm{k}}=$ the fixed effect of $\mathrm{k}^{\text {th }}$ animal group (imported and farm bred)

$\mathrm{P}_{1}=$ the fixed effect of $1^{\text {th }}$ parity $(1=1,2,3,4,5$ and $\geq 6)$

$\mathrm{e}_{\mathrm{ijk} \mathrm{k}}=$ random error associated with each observation.

\section{RESULTS AND DISCUSSION}

Milk production performance of pure Jersey cows

The lactation performance of dairy cattle is usually measured by determining the total milk yield per lactation, average daily milk yield and lactation length. Results of the least square means and standard errors for LMY, DMY and LL are summarized in Table 1. The overall lactation milk yield and standard error of LMY for pure Jersey cows in the present study was $2166.82 \pm 26.70 \mathrm{~kg}$. The result obtained in this study was comparable to the reports of Direba et al. (2015) who reported a value of $2155 \pm 16.4 \mathrm{~kg}$ and Yosef (2006) who reported a value of $2200.25 \pm 112 \mathrm{~kg}$ for Jersey breed, respectively. Lower values were reported by Habtamu et al. (2009) who reported a value of $1691.59 \pm 27.55 \mathrm{~kg}$ for Jersey breed. The overall least square mean and standard error of daily milk yield for pure Jersey cows in the present study was $6.37 \pm 0.05 \mathrm{~kg}$. The result of the present study was similar with the finding of Direba (2012) who reported a value of $6.25 \mathrm{~kg}$ for pure Jersey cows. The overall least square mean and standard error of LL for pure Jersey cows in the present study was $344.89 \pm 3.81$ days. This result was higher than Habtamu et al. (2009) who reported a value of $318.42 \pm 3.92$ days and Direba et al. (2015) who reported a value of $336.17 \pm 2.3$ days for Jersey cows, respectively.

\section{Effect of animal group}

Lactation length was significantly $(\mathrm{P}<0.001)$ affected by animal group. Lactation length was higher for imported cows than those reared on farm. This result is in line with the finding of Habtamu et al. (2009) for Jersey cows. DMY was significantly $(\mathrm{P}<0.01)$ affected by animal group. Farm breed animals were produced higher DMY than imported animals. This variation might be due to the difference of environment (feeding management and climate condition) where the animals were kept. However, animal group did not have significant effect lactation milk yield trait.

\section{Effect of calving period}

Calving period had significant effect on LMY ( $p<0.0001)$. This result agreed with Direba et al. (2015) for pure Jersey breed and Kefale et al. (2020) for Holstein Friesian crosses with Boran. The two calving periods (20032005 and 1994-1996) were the most favourable calving period for animals to perform better lactation milk yield. The highest average lactation milk yield was observed during 2003-2005 (2603.58 $\pm 59.27 \mathrm{~kg})$ while the lowest lactation milk yield was recorded in 1991-1993 $(1730.73 \pm 55.91 \mathrm{~kg})$. Low performance of cows which calved in during 1991-1993 could be related to management problems like shortage of feed and health problems as a result of regime change in which the farm was financed and funded by government. The variation in lactation milk 
yield from one-calving period to other could be attributed to changes in herd size, stage of lactation, change of the climate and inconsistent management (feeding) practices introduced from year to year.

Period of calving had significantly $(\mathrm{P}<0.0001)$ affected daily milk yield. This result was agreed with Kefale et al. (2020) for HF x Boran cross. The highest daily milk yield recorded was during 2003-2005 and the lowest daily milk yield was recorded during 1991-1993 calving periods. Low DMY for cows which calved in during 1991-1993 could be related to management problems like shortage of feed and health problems as a result of regime change in which the farm was financed and funded by government.

Lactation length was significantly $(\mathrm{P}<0.0001)$ affected by fixed effect of calving period. This result is similar with Direba et al. (2015) for Jersey cows and Kefale et al. (2020) for HF x Boran cross. Highest lactation length was recorded on cows born in during 2015-2017 and the lowest was observed during 1988-1990 with a difference of 116.83 days (Table 1). The variation of lactation length with the different calving period might be explained by the variation of annual rainfall, which directly or indirectly is associated with the availability of feeds.

\section{Effect of calving season}

Calving season did not have significant $(\mathrm{p}>0.05)$ effect on LMY. This result agreed with the finding of (Yosef 2006; Aynalem et al. 2009; Million et al. 2010; Direba et al. 2015). On the other hand, Gebregziabhere et al. (2014), Tadesse (2014) and Kefale et al. (2020) found that calving season did have significant effect on LMY.

Calving season group did not show a significant effect on daily milk yield. This result was agreed with Aynalem et al. (2009) for HF x Boran cross. Season of calving did not influence ( $\mathrm{p}>0.05)$ lactation length. This result was in line with the finding of (Aynalem et al., 2009; Habtamu et al., 2009; Direba et al., 2015; Kefale et al. 2020).

\section{Effect of parity}

Lactation milk yield significantly $(\mathrm{p}<0.0001)$ differed among different parity. This significant effect of parity on LMY was similar with the reports of Direba et al. (2015) for pure Jersey breed, Kefale et al. (2020) for Holstein Friesian crosses with Boran and Gebregziabhere et al. (2014) for HF x Boran and Jersey x Boran. In contrast, Yosef (2006) reported that parity did not have significant effect on LMY for Jersey and HF cattle. Maximum lactation milk yield was observed in parity two $(2315.90 \pm 43.85 \mathrm{~kg})$ and minimum yield was recorded in parity greater than or equal to six $(1948.66 \pm 48.68 \mathrm{~kg})$. There was no significant difference between parity four and five on LMY.

There was significant $(\mathrm{P}<0.0001)$ difference among parity of cow on daily milk yield. This result was agreed with the finding of Gebregziabhere et al. (2014) for Jersey x Bor and HF x Boran and Kefale et al. (2020) for HF x Boran. Higher daily milk yield was observed in parity five and lower was recorded at parity one. Cows with lower parities had lower daily milk yield than those of higher parities. This might be because the size of udder and teats increased with the maturity of the cows and subsequently the milk production capacity increased with parity.

Lactation length was significantly $(\mathrm{P}<0.0001)$ influenced by parity and this result was agreed with the findings of Direba et al. (2015) and Kefale et al. (2020). The longest lactation length was observed in parity two and the shortest was recorded on parity greater than or equal to $\operatorname{six}(\geq 6)$. 
Table 1. Least square means and standard errors of lactation milk yield, daily milk yield and lactation length of Jersey cattle

\begin{tabular}{|c|c|c|c|c|}
\hline \multirow[t]{2}{*}{ Sources of variation } & \multirow[t]{2}{*}{$\mathbf{N}$} & LMY(Litres) & DMY(Litres) & LL (days) \\
\hline & & $\mathbf{L S M} \pm \mathbf{S E}$ & $\mathbf{L S M} \pm \mathbf{S E}$ & $\mathbf{L S M} \pm \mathbf{S E}$ \\
\hline Overall mean & 2912 & $2166.10 \pm 26.71$ & $6.37 \pm 0.05$ & $344.89 \pm 3.81$ \\
\hline CV $(\%)$ & & 38.52 & 23.81 & 35.62 \\
\hline Animal group & & Ns & $* *$ & $* * *$ \\
\hline Imported & 1048 & $2202.47 \pm 54.23$ & $6.18 \pm 0.10^{\mathrm{b}}$ & $361.29 \pm 7.74^{\mathrm{a}}$ \\
\hline Farm breed & 1864 & $2130.81 \pm 26.48$ & $6.56 \pm 0.05^{\mathrm{a}}$ & $328.57 \pm 3.78^{b}$ \\
\hline Calving period & & $* * * *$ & $* * * *$ & $* * * *$ \\
\hline $1988-1990$ & 693 & $2062.08 \pm 58.17^{\mathrm{d}}$ & $7.27 \pm 0.11^{\mathrm{b}}$ & $282.15 \pm 8.29^{f}$ \\
\hline 1991-1993 & 276 & $1730.73 \pm 55.91^{\mathrm{e}}$ & $4.27 \pm 0.10^{\mathrm{f}}$ & $367.81 \pm 7.97^{\mathrm{c}}$ \\
\hline 1994-1996 & 275 & $2528.84 \pm 51.00^{\mathrm{ab}}$ & $6.92 \pm 0.10^{\mathrm{c}}$ & $365.47 \pm 7.28^{\mathrm{bc}}$ \\
\hline 1997-1999 & 262 & $2257.29 \pm 56.26^{\mathrm{bc}}$ & $6.73 \pm 0.11^{\mathrm{c}}$ & $331.87 \pm 8.03^{\mathrm{cd}}$ \\
\hline $2000-2002$ & 313 & $2367.80 \pm 56.55^{b}$ & $7.31 \pm 0.11^{\mathrm{b}}$ & $325.07 \pm 8.07^{\mathrm{e}}$ \\
\hline $2003-2005$ & 288 & $2603.58 \pm 59.27^{\mathrm{a}}$ & $7.62 \pm 0.11^{\mathrm{a}}$ & $341.88 \pm 8.45^{\mathrm{d}}$ \\
\hline $2006-2008$ & 254 & $2221.54 \pm 61.70^{c}$ & $6.15 \pm 0.12^{\mathrm{d}}$ & $380.66 \pm 8.80^{\mathrm{b}}$ \\
\hline 2009-2011 & 153 & $2143.83 \pm 74.48^{\mathrm{cd}}$ & $5.74 \pm 0.14^{\mathrm{e}}$ & $377.15 \pm 10.63^{\mathrm{ab}}$ \\
\hline 2012-2014 & 194 & $1791.83 \pm 68.24^{\mathrm{e}}$ & $5.91 \pm 0.13^{\mathrm{de}}$ & $304.21 \pm 9.74^{\mathrm{bd}}$ \\
\hline $2015-2017$ & 163 & $2243.19 \pm 73.36^{\mathrm{bc}}$ & $5.75 \pm 0.14^{\mathrm{e}}$ & $398.51 \pm 10.47^{\mathrm{a}}$ \\
\hline 2018-2019 & 41 & $1877.87 \pm 134.91^{\mathrm{de}}$ & $5.93 \pm 0.25^{\mathrm{de}}$ & $319.16 \pm 19.25^{\mathrm{ed}}$ \\
\hline Calving season group & & Ns & Ns & Ns \\
\hline Dry season & 1517 & $2160.67 \pm 31.99$ & $6.34 \pm 0.06$ & $343.67 \pm 4.56$ \\
\hline Short rain season & 639 & $2192.71 \pm 38.48$ & $6.43 \pm 0.07$ & $349.25 \pm 5.49$ \\
\hline Main rain season & 756 & $2145.23 \pm 37.23$ & $6.33 \pm 0.07$ & $341.79 \pm 5.31$ \\
\hline Parity & & $* * * *$ & $* * * *$ & $* * * *$ \\
\hline 1 & 830 & $2061.38 \pm 43.80^{\mathrm{cd}}$ & $5.75 \pm 0.08^{c}$ & $360.81 \pm 6.25^{\mathrm{a}}$ \\
\hline 2 & 722 & $2315.90 \pm 43.85^{\mathrm{a}}$ & $6.55 \pm 0.08^{\mathrm{a}}$ & $362.57 \pm 6.26^{\mathrm{a}}$ \\
\hline 3 & 449 & $2132.36 \pm 45.80^{\mathrm{bc}}$ & $6.36 \pm 0.08^{\mathrm{ab}}$ & $339.95 \pm 6.53^{b}$ \\
\hline 4 & 341 & $2225.43 \pm 49.82^{\mathrm{ab}}$ & $6.65 \pm 0.09^{\mathrm{a}}$ & $343.09 \pm 7.11^{\mathrm{ab}}$ \\
\hline 5 & 245 & $2315.11 \pm 56.85^{\mathrm{ab}}$ & $6.68 \pm 0.12^{\mathrm{a}}$ & $348.24 \pm 8.11^{\mathrm{ab}}$ \\
\hline$\geq 6$ & 325 & $1948.66 \pm 48.68^{\mathrm{d}}$ & $6.22 \pm 0.09^{\mathrm{b}}$ & $314.86 \pm 6.95^{\mathrm{c}}$ \\
\hline
\end{tabular}

\section{Conclusions}

From this study, the milk performance of pure Jersey dairy cattle was influenced by genetic and non-genetic factors. Animal group had significant effect on daily milk yield (DMY) and lactation length (LL) traits. Year of calving and parity had significant effect on all milk production traits. Season of calving does not significantly affect milk production traits. Knowledge on the effect of these non-genetic factors would help in making management decisions for improvement of the herds. Improvement on the level of feeding, breeding and health management should be done for improvement of milk production traits.

\section{References}

Aynalem Haile, B. K., Joshi, Workneh Ayalew, Azage Tegegne and A., Singh (2009). Genetic evaluation of Ethiopian Borena cattle and their crosses with Holstein Friesian in central Ethiopia: milk production traits. Animal, 3: 486-493.

CSA (Central Statistical Agency) Federal Democratic Republic of Ethiopia (2019/2020). Agricultural Sample Survey Report on livestock and livestock characteristics (private peasant holdings). Addis Ababa, Ethiopia.

Direba Hunde, Gábor Mészáros, Tadelle Dessie, Getnet Assefa, M. T. and J. Sölkner (2015). Milk Yield and Reproductive Performance of Pure Jersey Dairy Cattle in the Central Highlands of Ethiopia. Livestock Research for Rural Development.

Direba Hunde (2012). Survival, Reproductive and Productive Performance of Pure Jersey Cattle at Adea Berga Dairy Research Center in the Central Highlands of Ethiopia. MSc. Thesis, University of Natural Resources and Life Sciences. Vienna, Austria, 90 pp.

Fikre Lobago, Merga Bekana, Hans Gustafsson and Hans Kindahl (2007). Longitudinal observation on reproductive and lactation performances of smallholder crossbred dairy cattle in Fitche, Oromia region, central Ethiopia. Tropical Animal Health and Production. 39: 395-403. 
Firdessa R., Tschopp R., Wubete A., Sombo M., Hailu E., Erenso G., Kiros T., Yamuah L., Vordermeier M., Hewinson R.G., Young D., Gordon S.V., Sahile M., Assefa A., Berg S. (2012). High prevalence of Bovine Tuberculosis in dairy cattle in central Ethiopia: implications for the dairy industry and public health. PLoSOne, 2012; 7(12): e52851.

Gebregziabher Gebreyohannes, SkornKoonawootrittriron, Mauricio Aguirre Elzo and Thanathip Suwanasopee (2014). Genotype by Environment interaction effect on lactation pattern and milk production traits in an Ethiopian Dairy cattle population. Kasetsart Journal of Natural Science, 48: 38-51.

Habtamu Lemma, Kelay Belihu, Desie Sheferaw and Gebeyehu Goshu (2009). Milk production performance of Jersey cows at Wolaita Sodo state dairy farm, southern Ethiopia. Ethiop. J. Sci., 32(2):157-162.

Hunduma Dinka (2013). Reproductive performance of crossbred dairy cows under smallholder condition in Ethiopia. African Journal of Dairy Farming and Milk Production (AJDFMP) 1: 101-103.

Kefale Getahun, Million Tadesse, Direba Hunde and Yosef Tadesse (2020). Productive Performances of Crossbred Dairy Cattle at Holetta Agricultural Research Center. Ethiopian Journal of Agricultural Sciences, $30(2), 55-65$.

Million Tadesse and Tadelle Dessie (2003). Milk production performance of Zebu, Holstein Friesian and their crosses in Ethiopia. Livestock Research for Rural Development (15) 32003.

Million Tadesse, J., Thiengtham, A., Pinyopummin and S., Prasanpanich (2010). Productive and reproductive performance of Holstein Friesian dairy cows in Ethiopia. Livestock research for rural development, 22 (2).

Olawumi S.O. and Salako A.E. (2010). Genetic Parameters and Factors Affecting Reproductive Performance of White Fulani Cattle in South western, Nigeria. Global Veterinarian 5: 255-258.

Tadesse Birhanu (2014). Estimation of crossbreeding parameters in Holstein Friesian and Ethiopian Borancrosses for milk production and reproduction traits at Holeta agricultural research center, Ethiopia. MSc. Thesis, Haramaya University, Ethiopia, 83 pp.

Yosef Tadesse (2006). Genetic and Non-Genetic analysis of fertility and production traits in Holetta and Ada'a Berga Dairy herds. MSc. Thesis, Alemaya University, Ethiopia, 143 pp. 